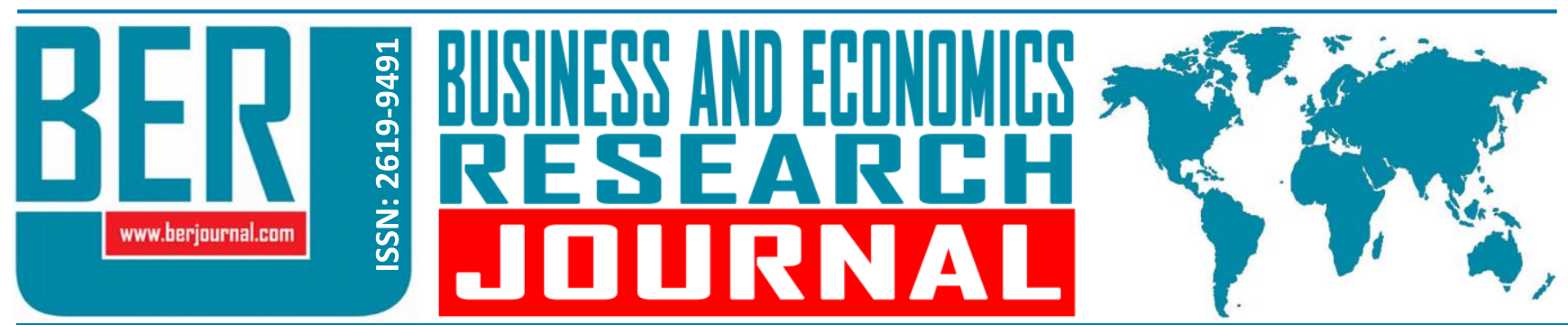

Business and Economics Research Journal Vol. 11, No. 1, 2020, pp. 15-31 doi: 10.20409/berj.2019.230

\title{
An Investigation of the Reasons for the Natural Resource Curse: Selected Country Cases
}

\section{Ayfer Gedikli ${ }^{\mathrm{a}}$}

Abstract: Ever since its growing importance, the natural resource abundance and economic growth relationship have been a hot field of study for researchers. In the existing literature, many studies pointing to the negative impact of natural resource endowment on economic growth performance. While some "blessed" natural resourceabundant countries enjoy their natural resource revenues and have a remarkable economic growth performance, many others are "cursed" despite having great natural resource wealth. Natural resource windfall may induce Dutch Disease with excessive rent-seeking, corruption, poor institutionalism, and democracy in resource-rich developing countries. The aim of this study is to investigate the causes of the natural resource curse in developing natural resource-rich countries. In this research, the sample natural resource-rich countries were analyzed between 1980 and 2018 to validate the existence of the natural resource curse in these countries. In the first part, the conceptual framework and reasons for the natural resource curse were explained in detail. In the second part, successful natural resource-rich country cases, as well as selected resource-rich developing countries, were compared according to their economic growth performances, their natural resource revenues, and degree of dependence of their economies on the natural resource revenues. In the last part, some policy suggestions were put forward to avoid a natural resource curse in developing countries.
Keywords: Natural Resource Abundance, Natural Resource Cursed Developing Countries, Dutch Disease, Natural Resource Curse, Commodity Price Volatility

JEL: N50, 013

$\begin{array}{ll}\text { Received } & : 10 \text { October } 2019 \\ \text { Revised } & : 07 \text { November } 2019 \\ \text { Accepted } & : \text { 13 December } 2019 \\ \text { Type } & : \text { Research }\end{array}$

Received : 10 October 2019

Type : Research

\section{Introduction}

Similar to today's excessive needs, natural resources were vital for previous years, particularly in the Industrial Revolution. In the 19th century coal, and the 20th century oil was a source of energy that was necessary for any industrial investment and economic growth. Therefore, traditionally in the economic literature, it was widely accepted that access to more natural resources, either nonrenewables such as coal, oil, and minerals, or renewables like forests and fish, provide acceleration to economic growth. (Karabegovic, 2009: 6). Despite its positive historical perception, many authors describe natural resources as a "double edges sword". On the one hand, natural resources provide economic growth by its significant contribution to national income. On the other hand, it may be harmful to long term economic growth by damaging the other sectors through crowding out effect (Moradbeigi \& Law, 2016: 97). Social conflicts, civil wars, authoritarian regimes, and severe poverty are the other common side effects of having natural resources. Particularly in developing natural resource-rich countries in which there are weak institutional structures and financial systems, natural resource abundance does not bring industrial growth as anticipated. Thus, based 
on many studies in the related literature, natural resources are considered as a "curse" more than a "blessing" (Di John, 2011: 167).

"Resource curse" can be defined as the negative impact of natural resource wealth on an economy. With a detail definition, the natural resource curse is being heavily dependent on natural resources in an economy that causes fiscal dependence, corruption, currency appreciation political monopolization, and crowding out effect on the other sectors. In other words, if windfall of resources is associated with slower economic growth, social conflicts, civil war, and an autocratic political regime, then we can mention about the natural resource curse (Wick \& Bulte, 2009: 140). So, the definition is pointing a high level of income from natural resources, poor governance, and corruption. World Energy Council (2016: 59) explains the natural resource curse in $4 \mathrm{~S}$ process:

- Stability: Resource price volatility causes uncertainty for governments.

- Scale: The governments of the natural resource exporter countries are almost $50 \%$ larger than the non-producer countries.

- Source: Since none of the projects financed by natural resource revenues are supported by taxpayers, governments are not accountable and transparent.

- Secrecy: Natural resource producer governments tend to hide their revenues.

One may think that the "natural resource curse" is faith for developing countries. However, there are some natural resource-rich developing countries such as Indonesia, Botswana, Chile, and Malaysia that showed a remarkable performance in managing their windfall natural resources. Those developing countries benefited their natural resources and could manage to have great economic growth performances by eliminating the side effects of having natural resources. In other words, they are "blessed" rather than "cursed" by their natural resources.

The aim of this study is to investigate the causes and the consequences of the natural resource curse in developing natural resource-rich countries. The research covers the period of 1980-2018. In the first part of the study, the conceptual framework and the reasons for the natural resource curse will be explained. Then, basic economic problems caused by the natural resource curse in the natural resource-rich countries will be analyzed. In this part, the economic channels of the natural resource curse will be explained in detail. Dutch Disease, price volatility, crowding out effect, and institutionalization problems will be the headlines of this part. In the second part, selected "natural resource blessed" countries, as well as sample resource-rich developing countries, will be handled. The sample countries will be compared according to their economic growth performances concerning their natural resource revenues and degree of dependence of their economies on the natural resource revenues. In the last part of the study, some policy suggestions to benefit natural resource abundance while avoiding the side effects of it will be put forth.

\section{Background Information on Natural Resource}

Natural resource abundance often brings wealth with dependence on abundant resources. At first glance, countries lacking these resources seem disadvantageous in the competition. Nevertheless, many natural resource-abundant countries that have fallen behind their resource-poor counterparts in terms of economic growth and sustainable development. Even among the natural resource-abundant countries, there is a discrepancy between the volume of natural resource revenue and economic growth. While some natural resource-rich countries can manage their natural wealth and become "blessed", some others cannot and face different economic problems as if they are "cursed". Oil and fuels are the well-known natural resources that can cause a curse to the owner countries (Tenorio, 2013: 9).

If natural resources provide a great advantage to those countries, why many natural resource-rich countries such as Nigeria, Venezuela, Angola or Chad still suffer from economic problems and poverty? Venezuela and Nigeria enjoyed high oil revenues after the sharp increases in oil prices in the 1970s and 1980s. However, the revenue started to decline in the 1990s. In all these countries the economies had a boom and 
a collapse with a crisis after a negative shock. Nigeria, for example, had a military dictatorship during this period and while there were high oil revenues, the government spent the resource revenues mostly on wasteful industrial projects. Contrary, Venezuela had been a good functioning economy of South America with no military governments or coups. However, Venezuela also experienced low growth rates with massive volatility (Isham et al., 2002: 6). In recent years, Venezuela has been suffering from hyperinflation and devastating economic problems. It is a fact that after many years of extraction of natural resources, most resource-abundant countries are still underdeveloped whereas natural resource-poor countries show far better economic and political performance. The resource-poor countries, such as Korea, Japan, Singapore, and Hong Kong recorded significant growth performance and they became highly industrialized countries that they can compete with other advanced economies in the world market (Sachs \& Warner, 2001: 828). To support this approach, Sachs and Warner (1995, 2001), Matsen and Torvik (2005), Wick and Bulte (2006, 2009), Caselli and Cunningham (2009), Reisinezhad (2018), and many other researchers indicated the natural resource curse in these countries with different aspects.

In the literature, having a great amount of resources with poor economic performance is explained with the "natural resource curse" phenomenon. At the early periods of the discovery of natural resources, countries enjoyed resource rents which provide a great push to economies to reach a higher level of development (Veisi, 2017: 19). One of the pioneer studies on the natural resource curse was done by Sachs and Warner $(1995,2001)$. The authors indicated the importance of primary products (for those countries, the primary product is the natural resource) in a country's export in GDP per capita growth. They also reported that resource abundance has a negative effect on resource-abundant countries. Many later studies were consistent with their findings and pointed the curse of natural resources such as the research done by Atkinson and Hamilton (2003). The researchers found a significant and negative relationship between natural resource abundance and economic growth. Particularly, in the countries where the natural resources revenue management policies and public expenditure policies are poor, there is a low rate of genuine saving. The authors also expressed that poor governance may lead to the inability to manage large resource revenues sustainably.

On the other hand, in the literature, there are some studies that pointed out that natural resource abundance does not cause the natural resource curse. In their study, Karamelikli, Akalin, and Arslan (2017) investigated the dynamic relationship between oil exports and nonoil exports, imports and economic growth in OPEC countries over the period 1972-2013. The authors concluded that the increase in oil exports has a positive effect on the GDP of all countries. The authors also found that the increase in oil exports has negative impacts on the non-oil exports of some countries such as Iran, Iraq, and Nigeria. This indicated that the natural resource-rich countries are not completely exposed to the negative effects of Dutch disease.

There are many reasons for the natural resource curse. While some of the authors explain the resource curse with "Dutch Disease", some others blame political and institutional factors. The "Dutch Disease" phenomenon was popular in the 1980s. According to his phenomenon, a boom in mineral production, by pushing the real exchange rate upwards, affects nonhydrocarbon sectors like the manufacturing sector negatively. In the 1990s, Nigeria and Russia had to experience this problem because of oil and minerals extraction. Natural resource extraction had crowding out effects on their traditional sectors such as manufacturing and agricultural sectors. In the Nigeria case, the natural resource endowment hindered agricultural exports (Mosley, 2017: 1).

Regardless of the reason, the natural resource abundance may bring weak economic growth with a higher degree of authoritarian governance that contains patronage, clientelism, and overexpansion of the public sector. This is because most of the oil-rich developing countries spend more on security and repression forces. It should be emphasized that a country may be cursed only if the economy is dependent on a few specific natural resources without having accountability and democratic state institutions. There are many "natural resource blessed" countries such as Norway, Australia, Canada, and Malaysia. The common feature of these countries is that all of these countries have established democracies before they have a natural resource export boom (Amundsen, 2017: 18). 
Natural resource abundance may undermine economic development through the "rentier effect" or the "untimodernization effect". The rentier effect is faced if the national budget of a country is heavily based on fuel or mineral exports, if that country expends the revenue on lavish and unnecessary expensive infrastructure projects, avoids accountability, represses opposition movements and independent business groups or public opinion. Increasing the rentier effect, increases growth volatility by keeping the government away from the institutional reforms, policies improving accountability and poor export goods diversification (Isham et al., 2002: 8).

In Figure 1, crude oil prices for the 1950-2018 period are shown. 1970, 1980, 1990, 2000 and 20082009 are the years of sharp increases in crude oil prices. Contrary, 1998 and 2014-2015 are the years of declines in oil prices.

Figure 1. Crude Oil Prices (1950-2018) (US\$)

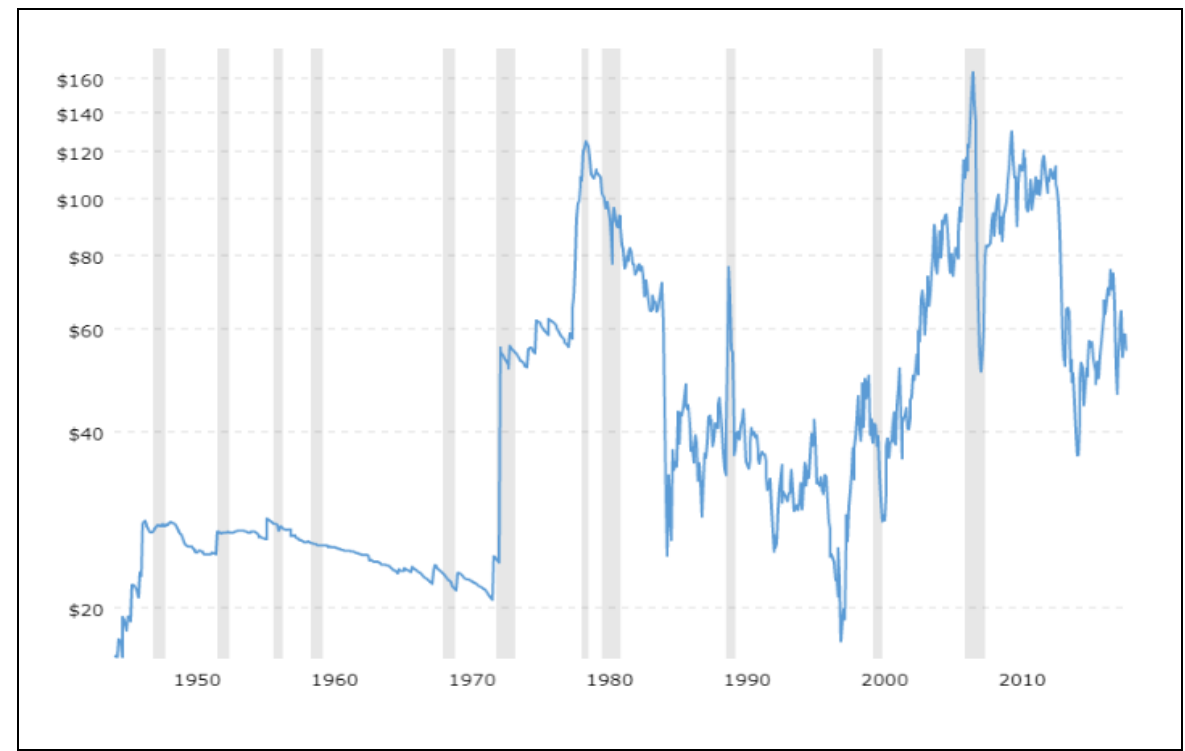

Source: Macrotrends (2019).

In Figure 2, total natural resource rents as a percent of GDP are illustrated for selected natural resource-rich countries.

Figure 2. Total Natural Resource Rents (\% GDP) for Selected Countries (1980-2018)

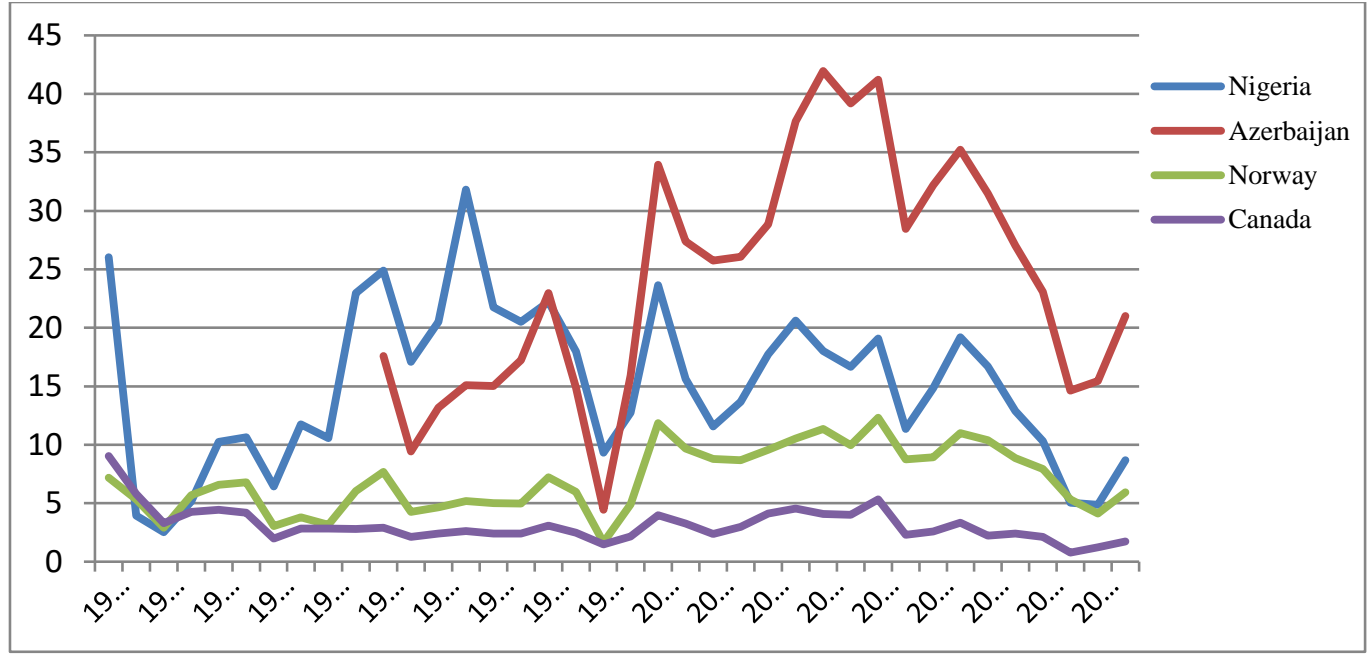

Source: World Bank (2019) Total Natural Resource Rents (\% of GDP) 
As illustrated in Figure 2, total natural resource rents (\% of GDP) for Nigeria and Azerbaijan are higher than Norway and Canada. Because of the shrinks in oil prices in 1998, there were declines in natural resource rents in all countries. However, comparing with Norway and Canada, Nigeria and Azerbaijan had sharper declines in that period. Similarly, between 2012-2016, there were also more declines in resource rents in Nigeria and Azerbaijan. More severe effects of decreasing resource rents as \% of GDP on Nigeria and Azerbaijan can be explained with a higher dependence on the natural resources and less diversification. Increasing dependence on the natural resource revenues in an economy may bring the natural resource curse.

However, in their study, Cust, Halonen, and Harding (2018) investigated 59 resource-rich countries and found no evidence of the natural resource curse. They concluded that more than half of the countries enjoyed increasing GDP per capita due to oil and gas production. Therefore, it should be underlined that natural resource endowment is not a "curse", but it can become a curse if the political authorities cannot manage it wisely. "How to manage" should be the critical question to be blessed by the natural resource windfall. In the next part of the study, economic and politic reasons for the natural resource curse will be explained.

\section{Channels of Resource Curse}

Natural resource extraction has increased globally since the 1970s. Ten greatest economies are responsible for $68 \%$ of global extraction in 2017 , while it was $64 \%$ in 1970 . China is the leading country with more than a third of all material extraction in 2017. Global extraction of fossil fuels such as coal, petroleum and natural gas has increased from 6.2 billion tons in 1970 to 15 billion tons in 2017. Although the value of fossil fuel extraction increased, their share decreased from $23 \%$ in 1970 to $16 \%$ in 2017. Natural gas showed a growth rate of $2.8 \%$ annually. This rate is higher than oil extraction which has a rate of $1.3 \%$ growth. This decline can be explained by the expanded electricity generation capacity of coal/gas-fired power stations. Similarly, coal use decreased due to improvements in the renewable energy sector and energy efficiency strategies. Comparing the extraction amount with per capita, Australia has the highest extraction performance per capita with 93.3 tons. Canada follows Australia with 36.7 tons per capita. As a general, Asia and Pacific region had 57\% of total extraction (UN Environment, 2019: 43-44). These data show that Australia, China, and Canada enjoyed natural resource extraction and natural resource exports; and they increased their national income with resource revenues. In other words, natural resource abundance did not cause curse, instead, it brought wealth to these countries.

Then, what are the basic differences between the natural resource blessed countries and the natural resource cursed countries? Which factors cause the countries to be cursed or blessed? In the next part, the reasons for the natural resource curse will be explained.

\subsection{The Dutch Disease}

One of the well known economic channels of the natural resource curse is the "Dutch Disease". The name "Dutch Disease" comes from the Netherlands' experience of the 1960s and 1970s by having a large number of natural gas exports and facing an appreciation in the real exchange rate. Dutch Disease can be seen in most of the emerging countries whose economies are heavily dependent on the extraction of natural resources. According to the Dutch Disease mechanism, the first phase starts with discovering a new natural resource. In this phase, there is a natural resource boom due to the "spending effect" which is a result of the expansion of export-oriented tradable resource increase. As export increases, demand for both tradable and nontradable goods and services increases. In this period, while the price of nontradable goods and services increase, the price of tradable goods which are determined in international markets do not increase. Besides, the increase in export triggers the appreciation of the real exchange rate which leads to a decrease in the relative prices of foreign exchange and appreciation of the value of the domestic currency (Karabegovic, 2009:8). In its boom period, natural resources endowment makes the resource-rich country less competitive in manufacturing export which is critical for economic growth. Furthermore, a country whose economy is heavily based on natural resources is more fragile and sensitive to external shocks that may have severe negative impacts on the economy (Isham et al. 2002: 10). 
Dutch Disease also negatively affects the labor market. The contraction in nonhydrocarbon sectors urges labor and capital to shift from the manufacturing sector to the resource sector and the nontradable sector. Nonhydrocarbon sectors may have another disadvantageous effect with raising wages because of the rents of the booming natural resource sector (Karabegovic, 2009: 8). In most cases, the booming natural resource sector has significant rents which is a result of the great difference between the price and the production cost. As there is a boom in the natural resource sector, it pulls labor and other production inputs from other sectors to that sector. High rates of profit allow firms to raise wages to attract an increasing number of employees that puts pressure on the manufacturing sectors to offer a higher level of wages. Moreover, the more employees prefer to work in the natural resource sector, the less production and learning-by-doing effects in the manufacturing sector. And also, a booming resource sector increases competition for capital. At the end of the booming phase, the manufacturing sector shrinks and the natural resource sector tries to compensate international trade (Gerelmaa \& Kotani, 2016: 312). Even though the export level stays the same with increasing natural resource exports, the contraction of the manufacturing sector may negatively affect the economic growth if that sector is more productive than the natural resource sector.

Feltenstein (1992) investigated the relationship between oil price increases and the Dutch disease for Mexico over the period 1986-1987. The author found that Dutch disease was the result of real exchange rate changes and price changes because of migration out of agriculture.

\subsection{Volatility}

In the recent past, there were sharp natural resource good price changes such as oil shock in the 1970 s which had devastating effects on both resource importer and resource exporter economies. The price volatility of natural resources can increase the uncertainty of the return on investment. Since natural resource goods' prices tend to be inelastic, the price volatility of their supply and demand becomes more critical. A price volatility signal may increase the capital-output ratio which leads to more investment risks. Investment risks and price volatility may raise the fluctuations that threaten long-term sustainable economic growth of the resource-dependent economy. These fluctuations raise the public's uncertainty of return of investments which leads to current consumption instead of long-term savings or investments (Shao \& Yang, 2014: 636).

As a solution to this problem, Moradbeigi \& Law (2016: 98) suggested that a better functioning financial system can observe the negative effects of oil volatility on growth. It is a fact that in case of a financial crisis, it will be hard to find funds both for high wealth entrepreneurs and low wealth entrepreneurs. Since the marginal productivity of low wealth entrepreneurs is higher, that group will be affected more with the productivity shocks in the imperfect capital markets. So, deeper financial markets absorb the effect of real shocks by alleviating cash-flow problems for low wealth enterprises.

To protect economies from the negative effects of resource revenue volatilities, some governments initiated special wealth funds for long-term investments. Wealth funds were established to protect the country's budget not only from the resource price volatilities but also hedge for times of low prices. They require transparent legislation for withdrawal, deposit and investment as well as monitoring and auditing by independent authorities. One of the earliest special oil revenue funds is the Kuwait Investment Authority that was established in 1953 by British authorities. In 2015, there was a total of 68 national or state sovereign wealth funds whose market value was almost $\$ 7.2$ trillion. The largest sovereign wealth fund is the Norway Government Pension Fund that protects Norway's economy from the natural resource curse. (World Energy Council, 2016: 59).

\subsection{Trends in World Commodity Prices}

Sachs and Warner (2001:837) pointed out that, resource-abundant countries tend to have higher commodity prices which lead to having negative consequences on their export-led growth. As Di John (2011: 169) reported, the oil boom can motivate more investments in nontrade investments and reduce 
manufacturing investments. Thus, the price of nontraded goods rises more than the price of nonoil traded goods because of the exchange rate appreciation. Moreover, the manufacturing sector becomes less competitive as a result of rising wages. As there is no productivity change in the manufacturing sector, increasing wages increases labor costs which leads to a loss in manufacturing competitiveness.

Goderis and Malone (2011: 389) investigated 90 countries for the period 1965-1999. The researchers reported that uncertainty about future commodity export prices increases long term inequality. A similar empirical result was found by Carmignani (2013). Carmignani (2013: 425) concluded that resource-rich countries may experience higher volatility of growth since there is a higher risk of changes in international commodity prices. If there is a recession, it is necessary to implement the expansionary policies which benefit the rich but ignores the poor. In this case, the volatility effect may impact human development negatively.

\subsection{Poor Taxation}

As a general, comparing with developed countries, developing countries collect a lower level of tax. In natural resource-rich countries, this gap is even greater. As the government has a greater amount of revenue from the natural resource export, it doesn't need to get tax revenue. In other words, natural resource endowment has a negative effect on tax collection in these countries. Taxation is actually an invisible contract between taxpayers and the government. Reliance on tax revenues urges the government to spend the revenues on more important and necessary investments for society. Besides, paying taxes provides the taxpayers to monitor and having the right to criticize the government. Nevertheless, in the resource-rich countries, instead of tax revenues, natural resource revenues are allocated in public expenditures. Therefore, less dependence on tax revenues brings less accountability and less transparency. In other words, governments do not feel to be responsible to oversee how and on which investment revenues are allocated. As a result of reliance on natural resources excessively will bring less tax collection and weaker tax systems in those countries (Veisi, 2017: 32-33). Furthermore, less dependence on taxation may hinder the development of a representative political system. Instead, it encourages autocracy. Low-taxed taxpayers request less accountability from their government that leads to less demand to improve institutional quality (Busse \& Gröning, 2011: 2).

\subsection{Political Economic Channels of the Resource Curse}

In the political economy mechanism, an increase in resource revenue leads to a decline in the economy's total value addition. In this case, in the successful resource-rich countries, the political leaders induce greater investments such as better infrastructure, better legislation, and more transparency in project management to have a higher level of economic growth and more exploitation of resource rent. Contrary, some others cause a deep collapse in the economy after a boom period. One of the reasons for this mechanism is to desire to keep the power in hand. One way to keep the power is to make the society happy with favors such as providing opportunities for the private sector. The primary reason for unproductive public expenditures is to protect the power of political elites. The second aim is that by making the citizens happy, there will be less possible to have conflicts or protests. This motivation also urges political elites to spend more on productive activities. However, despite providing all these facilities, other groups of people demand more share from the natural windfall. The higher expectation from society will bring more risk of conflicts. To keep this risk under control, there will be more authoritarian management. Political elites will transfer the resource rents to more wasteful investments such as security apparatus (Caselli \& Cunningham, 2009: 628631). Alongside income injustice, revenues from extracting natural resources are mostly spent on patronage to mitigate reactions among the population. This is called the spending effect which makes pressure on democracy. Finally, increasing patronage induces rent-seeking and corruption among the population (Busse \& Gröning, 2013: 2). Rent-seeking and corruption may trigger civil, religious, ethnic, regional and other political conflicts. All these conflicts are for sharing the windfall resources. In many resource-rich countries, coups and dictatorial regimes are also very common (Caselli, 2006:16). There is also a wealth effect on a natural resource. The more natural resource rent, the less political elites' marginal utility of consumption. This may bring more leisure that will generate a curse (Caselli \& Cunningham, 2009: 631). 
In short, the reason why some governments cannot manage the natural resource curse is highly related to the misbehaviors of political elites. In his study, Caselli (2006: 16) emphasizes on this problem. The researcher included 10 Sub-Saharan natural resource windfall countries in his study. South Africa, Uganda, Ghana, and Cote d'Ivoire were not much different in economic and political situations. All countries had political struggles and there was high uncertainty for even the near future. Among them, Nigeria was the country with the largest resources. However, despite having great proven oil reserves, Nigeria could not overcome its economic problems. Since the 1970s the country has exported \$10bn worth of oil, but unfortunately, the fraction of the population living on less than $\$ 1$ per day has increased from $36 \%$ in the 1960 s to $70 \%$ in the 2000s (Caselli \& Cunningham, 2009: 629).

The political-economic channels of the natural resource curse can be grouped under institutional problems, corruption, poor democracy, human capital degradation, transparency and accountability problems.

\subsubsection{Institutional Problems}

In the literature, some authors claim that institutional weakness paves the way for low economic growth performance via the natural resource curse. Some others express that having natural resource rent weakens institutions. The weakening process can be defined as a lack of necessary allocation of resources by the public sector. In those countries, political authorities take the power of allocating the resources. Therefore, in many developing resource-rich countries, governments are so weak that they cannot resist the expectations of interest groups who expect rent from natural resources. Since interest groups have both political and financial power on the governments to force them, natural resource management policies are designed according to their expectations (Mosley, 2017: 2).

In their study, Mehlum, Moene, and Torvik (2006) analyzed the relationship between institutional quality and economic growth in 42 resource-rich countries. The authors concluded that successful economic growth performance is highly related to the institutional quality in resource-rich countries. They pointed that there are some resource-rich countries such as Australia, Canada, and Botswana which could manage to have high economic growth whereas resource-rich countries like Nigeria, Zambia or Sierra Leone could not benefit their natural resources to have high economic growth performance. The basic difference between the economic performances of the sample successful and unsuccessful countries is institutional structure. The authors used the terms "grabber friendly institutions" and "producer friendly institutions". If a resource-rich country has a grabber friendly institutional structure, that country shows a low economic growth performance. Grabber friendly institutions provide a corrupt business environment. Contrary, if that resource-rich country has a producer friendly institution, then this country shows a good economic growth performance (Mehlum, Moene \& Torvik, 2006: 16). Sala-i Martin and Subramania (2003) also reached similar findings. The empirical results for Nigeria for the period of 1970-1998 showed that there is a nonlinear impact on the growth of natural resource abundance under poor institutional quality.

\subsubsection{Corruption}

In the literature, many studies are pointing out the relationship between the natural resource curse and corruption. As an example, at the beginning of the 20th century, Norway was one of the poorest countries in Europe. The country showed a remarkable performance by benefiting its abundant natural resources and became one of the richest countries in Europe. Norway owes this performance not only to its rich natural gas resources but also to be one of the least corrupted countries in the world (Mehlum, Moene \& Torvik, 2006: 3). According to Transparency International Corruption Perception Index Rankings (2018), Norway was recorded as the 7th least corrupted country in the world with a rate of 84 . Another resourcerich developed country Canada was ranked as 9 th with the rate of 81 . Australia also showed very satisfactory performance and it was ranked as 13th least corrupted country with a rate of 76 . A developing resource-rich country Chile got 67 and ranked 27th. Similarly, Botswana got 61 and ranked as 34. Contrary, a natural resource-rich developing country Sierre Leone was recorded as 129th with the rate of 30; Nigeria, another 
country with abundant natural resources was ranked as 144th with the rate of 27; Azerbaijan was recorded as 152 nd with the rate of 25 , and Chad was 165 th with the rate of 19.

Although the relationship between competition and corruption is not clear, it is obvious that less competition provides higher rents for the firms. This business ecosystem brings the close relationship with bureaucrats such as tax inspectors or regulators that can cause malfeasance. One of the case studies that explain the oil and corruption relationship is made by Ades and Di Tella (1999). The findings of the study indicated that Nigeria's oil revenue represents approximately $80 \%$ of government revenue. While a barrel oil was $\$ 2$ in 1973, by increasing 17 folds, it reached to $\$ 34$ at the end of 1981 (Ades \& Di Tella, 1999: 982-983). While Nigeria has enjoyed earning billions of dollars since the 1970s from oil exports, the fraction of the population living on less than $\$ 1$ per day has increased from $36 \%$ in the 1960 s to $70 \%$ in the 2000 s (Caselli \& Cunningham, 2009: 629). Instead of Nigerians, the ruling party and party officials became very rich. So, it can be concluded that natural resource rent may induce a lack of product market and competition that can finalize with corruption.

\subsubsection{Poor Democracy}

The countries which are more democratic and more peaceful are mostly natural resource-poor countries. Contrary, oil-rich countries such as MENA countries, Latin American or Asian countries neither democratic nor rich or peaceful. Their economic, political and social conditions are even worse than they were three decades ago. Venezuela has been experiencing a severe economic and political crisis in the current years; Algeria, Colombia, Nigeria, Sudan, and Iraq have been struggling with civil war. Although most of them are defined as "democracy", there are authoritarian regimes in those countries. While all these problematic countries are blessed with great reserves of natural resources, they are cursed with war, poverty, and conflicts because of having natural resource wealth (Ross, 2012: 1).

In most of the natural resource-rich countries, the authoritarian regimes do not allow democratization. However, if powerful groups force the authorities to make natural resource revenues available to the citizens, the weakening autocracy relaxes restrictions on democratization. Actually, democratization may bring the redistribution of wealth among different income groups in a fair way (Tornell \& Lane, 2015: 42).

\subsubsection{Human Capital Degradation and Income Inequality}

In the countries whose economies are heavily dependent on natural resource extraction do not need high-skilled labor or education. Comparing with the manufacturing sector, resource-based sectors need poor technology and less qualified human capital. Furthermore, even though employees are less qualified, they are paid more than manufacturing industry workers since the natural resource sector has higher profit rates. Therefore, the demand for high-skilled labor and related educational investments will decrease. Moreover, in the boom term of natural resource revenues, both government and public care natural capital. In this period, human capital accumulation is ignored. If households and youngsters can easily find jobs with higher wages in the natural resource sector, then they will give up having higher education as they get higher income with less effort. This may lead to a lack of incentive for human capital that will result in high-quality human capital and technology (Shuai \& Yang, 2014: 635).

Furthermore, there are many studies showed that the natural resource curse worsens income inequality. In his study, Reisinezhad (2018) investigated 40 countries over the period 1975-2015 and concluded that the Dutch Disease and deindustrialization bring more income inequality. If the redistribution of income is in favor of the rich, there will be an increasing demand for nontraded goods (luxury goods) that will worsen income inequality. Similarly, Carmignani (2013: 425) emphasized that higher resource abundance worsens average human development through the increasing inequality in income distribution. According to the authors, the reason behind this is the poor quality of institutions. Therefore, the inequality channel and institutional channel co-exist and affect the economy in the same way. In addition to them, Goderis and Malone (2011: 389) pointed out that after a resource boom, inequality between unskilled labor decreases in 
the first period. Especially after an oil and mineral boom, there is lower inequality in the year of boom. However, this positive effect slowly decreases until inequality returns to its pre-boom level in the long term. So, inequality starts to increase steadily over time and the initial positive impact of the boom disappears.

There is also a broad literature that emphasizes the relationship between poverty and natural abundance. Partridge, Betz, and Lobao (2012) investigated the Appalachian mountain region in the USA by using data over the 1990-2010 period. This area has rich coal mines, but weak local governance, poor educational and entrepreneurship attainment, poor environmental quality and bad economic conditions. The authors concluded that there is a reverse effect of the natural resource in the region and coal extraction is the main reason for poor economic and social conditions.

\subsubsection{Transparency, Accountability, and Resource Revenue Management}

As the public is informed about the actual amount of natural resource revenues and on which investments the revenues are expended, there will be more efficient revenue management. In other words, improving access to reliable data and information provide improvement in accountability for the generation and spending of revenues. Having the proper information, people can create their personal views, debate relevant issues and improve an idea about the management of natural resource revenues. Therefore, citizens need to have a democratic social environment to express their opinions to demand change. This brings the government and companies to account for their resource management and budget expenditures. Accountability and transparency will minimize corruption and the wasteful use of resource revenues. As a feedback effect, this will provide higher levels of revenues available for spending on education, health and infrastructure investments (Lujala \& Epremian, 2017: 60).

\section{Successful Resource-Rich Country Cases}

\subsection{Norway}

Different from many natural resource-rich developing countries, Norway enjoyed its great natural resource reserves and showed a remarkable economic growth performance. Norway has not only rich natural resources but also a well educated human capital that was the actual reason for the economic transformation. Natural capital was accepted as the second most important resource of the country. Norway's Petroleum Fund was established in 1990 and later it was called the Government Pension Fund to reflect its actual use. Since 2001, the Central Bank of Norway has been managing the Government Pension Funds on behalf of the Ministry of Finance. Besides, the independence of the Central Bank is ensured by the government. Norwegian pension fund which was accumulated by petro-rents, not only protected the country from Dutch Disease but also became a key asset for future generations as well as the current generation. Besides, Norwegian laws described the oil and natural gas reserves as common property resources. Accordingly, the legal rights of Norwegian people on those natural resources were clearly defined. The fund provided an amount of $\$ 100,000$ per person which is almost two times Norway's per capita GDP adjusted to purchasing power. Most of the oil rent is put into the Government Pension Fund, and a small portion of it is used in fiscal issues. Norway's fiscal policy is also very effective in managing natural resource revenue. The government used to transfer net oil tax revenue to the government budget to cover nonoil budget deficits. As years went by, the relative importance of the petroleum sector declined, and the share of oil revenues tend to increase to cover the same amount of budget deficits. Furthermore, the government tried to keep the value Norwegian krone from appreciation (Gylfason, 2011: 43-45). By investing rents abroad, appreciation of krone and reverse effects of Dutch Disease on the manufacturing industry were eliminated (Wick \& Bulte, 2009: 148). The government protected the nonoil sectors from the negative effects of dominating the oil sector. Therefore, the government went to economic diversification and protected the export and import performance of nonoil sectors. Low inflation rate and stable monetary and fiscal policies supported to reach high and sustainable economic growth (Gylfason, 2011: 44).

In their empirical studies, Holden (2013); Kumar, Toshniwal, and Gupta (2016), and Larsen (2006) reported similar findings of the success of Norway in managing its natural resource wealth. The Norway case 
is a good example for the other resource-rich countries. However, it should be noted that this country has high-quality political and legal institutions. There are also strict ethical principles to exploit oil rent in economical needs to leave enough resources to the next generations. Besides, there is a strong political commitment. All of the political parties followed macroprudential policies to protect the local currency krone from overheating because of appreciation. Therefore, despite Norway example is a successful case of managing natural resource windfall, this approach cannot be easily mimicked by the other natural resourcerich developing countries as most of those countries are lack of high political and legal institutions and deep democracy or social commitment (Wick \& Bulte, 2009: 148).

\subsection{Indonesia}

Until the coup that brought Suharto to power in 1965, Indonesia had difficulty in funding public expenditures and controlling the inflation problem. The new regime was "developmental authoritarian" and tried to initiate the policies which could provide high economic growth rates. Following the first oil shock in the 1970s, the government had to fight with increasing inflation and damaging competitiveness because of "Dutch Disease". To manage Durch Disease, like other resource-rich developing countries, the government tried to protect the domestic non-oil traded goods and sectors. The Suharto government couraged particularly the agriculture sector which led to a significant reduction in poverty. In the 1980s, the Suharto government realized that the macro policies were not effective enough to manage Dutch Disease. Therefore, the government initiated microeconomic reforms. Expenditure and exchange rate readjustments were the key policies. Accordingly, the government tried to give budget surplus and exchange rate depreciation protected the economy from the harmful effects of Dutch Disease. In the 1990s market liberalization continued. However, corruption could not be taken under control (Stevens, 2003: 14-15). Indonesia enjoyed the high oil export revenues and could manage the adverse effects wisely. In the oil export boom period, the country invested in human capital accumulation and growth. Besides, the government initiated a series of measures to support the development of the export-oriented manufacturing industry (Shao \& Yang, 2014: 636). The government was very sensitive in allocating the resource revenues to the investment projects as well as diversifying the sectors to improve the business environment and high-quality institutionalization. In their research, Taguchi and Soukvisan (2017) investigated the Dutch Disease effect on ASEAN countries. They concluded that while Indonesia experienced Dutch Disease effects in the period of 1970-1995, with its suitable macro policies, the country did not have such a bad experience in the 1995-2015 period that the other resource-rich developing countries had.

\subsection{Chile}

After the military the coup in 1973, Augusto Pinochet initiated an economic program which was based on agriculture, mineral and forestry export. The government provided subsidies for reforestation up to $75 \%$ of the total cost. Between 1975-1979, an effective exchange rate policy valued the local currency against the dollar. However, that success was heavily related to the copper industry. Although there were efforts to diversify the economy, high dependence on copper export showed the symptoms of Dutch Disease after the boom in the copper industry in 2003. Eightfold increase in copper prices in the 2003-2007 period, boosted the export volume which brought a boom phase. In this period, there was a flexible exchange rate regime. Because of high foreign capital inflow due to the high volume of copper export with eightfold prices, domestic currency Chilean peso appreciated relative to the dollar. Appreciation of local currency pushed the prices of the other tradable sectors. Parallel to the period of the boom in the copper industry in 2003, the inflation rates started to accelerate also. This was the evidence of affection of a sudden increase in copper export volume and increasing export revenues on the domestic money supply. This process was consistent with Dutch Disease. To protect the economy, the Chilean government applied monetary policy discipline and slowed money supply growth by sterilizing the cash inflows. Besides, the Chilean government initiated fiscal discipline with rising tax revenues and copper royalties. With these macroprudential policies, Chile's external assets increased vary fast and the country became a net debtor. Moreover, instead of spending the revenues and expending money supply, the government preferred to invest overseas (Ruehle \& Kulkarni, 2011: 69-7078). Well designed institutional framework and diversification strategies played an important role in 
overcoming the Dutch Disease problem in Chile. To do so, copper revenues were transferred to the state's budget and invested in financial markets depending on ore prices. That policy alleviated the effect of public finance on the copper market and even provided the stability of resource revenues. Besides, Chile tried to diversify the product structure of its export. Between 1960 and 2010, the share of ore and copper export declined by $30 \%$. These strategies brought budget surpluses in the 1981-2010 period. Even in the budget deficit periods, the deficit did not exceed more than 2\% of GDP (Wieprzowski, 2013: 151).

\subsection{Botswana}

Comparing with other developing resource-rich developing countries, Botswana did not suffer from natural resource curse with its wise macro policies. Contrary, Botswana could manage its resources with good governance and benefited its diamond wealth. In the boom period of diamond extraction between 19821987, spendings increased and there was a significant appreciation of the local currency. The government depreciated the exchange rate after the boom and tried to protect the economy via tight monetary policies. And up-to-date diamond revenues stayed high. Therefore, because of the effects of the booming minerals sector on exchange rates, there was a rapid growth of government spendings. To facilitate mineral revenues, a separate Development Fund was founded. The basic responsibility of the Development Fund is providing money on projects which are approved by the National Development Plan. The National development plan is the plan of Botswana that determines the five-year development plans of the country. Any project could not get funds from the Development Fund unless it is confirmed by the National Development Plan and the Ministry of Finance. The government preferred to invest the revenue of diamond in the foreign capital markets instead of bringing it to household consumption. This strategy could control the excessive spending effect of the boom period of natural resource revenues. In addition, a great portion of goods consumed domestically is imported from South Africa. Therefore, there is a limited risk of negative effects on the nontradable sector. The resource extraction sector caused a movement of higher qualified labor to move to the mining sector. They took the places of less-skilled workers who actually used to work in the agricultural sector. There were low skilled and less productive employees and caused a decline in the manufacturing sector. The agriculture sector was not effected deeply by the resource sector. The negative effect of the natural resources on agriculture is related to a rise in the local currency pula's value against the South African rand. (Pegg, 2010: 15-16).

\section{Comparative Analysis of Natural Resource-Rich Countries}

In this part of the study, natural resource-abundant countries will be compared according to their economic performances. Norway, Canada, and Australia are considered as the developed natural resourceabundant countries. Besides, in the literature, there are many studies that confirm their successful economic performance with their natural resource revenues. In Figure 3, GDP growth in US $\$$ of blessed natural resource-rich countries (Norway, Canada, and Australia) is shown. Other than the 2008 Global Crisis period, all countries showed remarkable economic growth performance. Although there were oil price declines between the 2014-2016 period, those countries did not have great problems with their GDP growth. Sustainability in those countries points to the soundness of their economies and successful diversification strategies.

In Figure 4, GDP growths of selected developing resource-rich countries are shown. The selected countries for Figure 4 are "blessed" developing natural resource-rich countries. Malaysia, Chile, Indonesia, and Botswana are developing countries that could manage their natural resource wealth and showed successful economic growth performances. 
Figure 3. GDP Growth for Blessed Natural Resource Rich Developed Countries (1980-2018) (US\$)

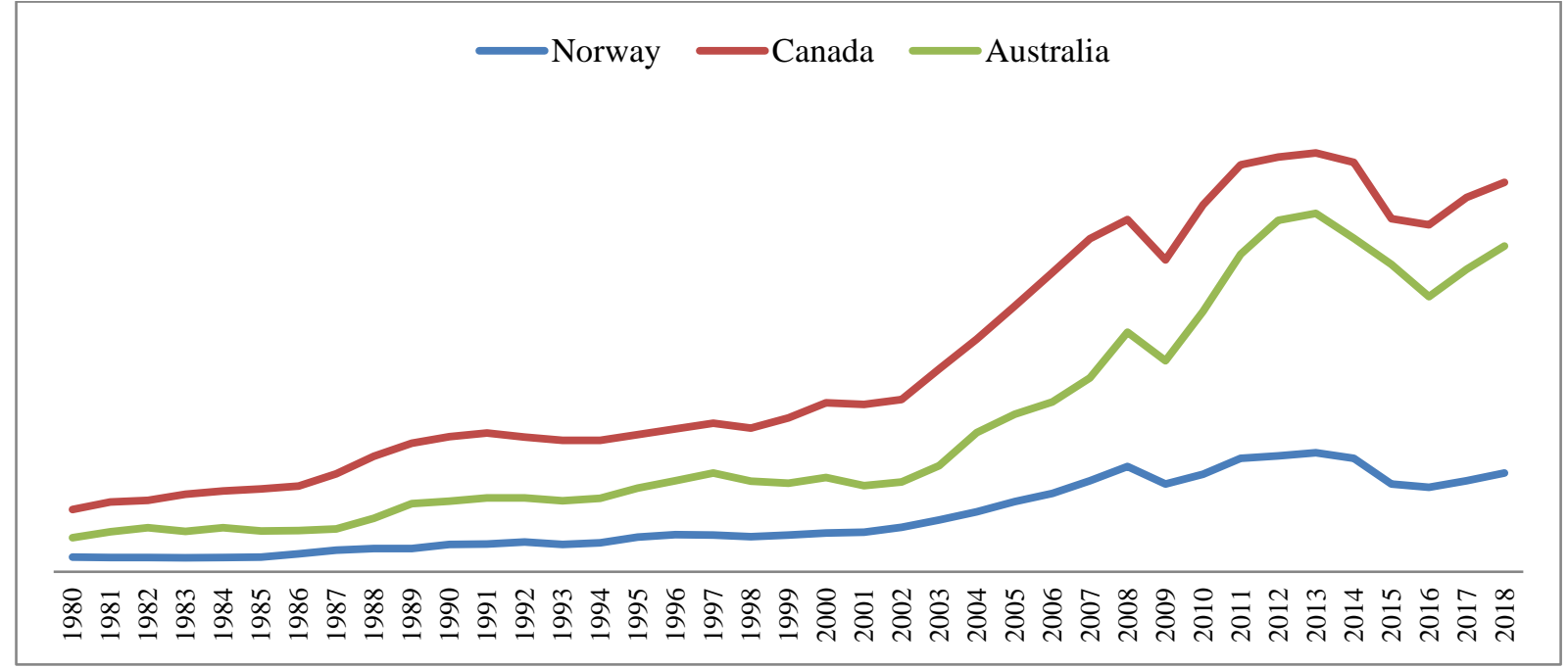

Source: The World Bank Data (2019).

Figure 4. GDP Growth for Blessed Natural Resource-Rich Developing Countries (1980-2018) (US\$)

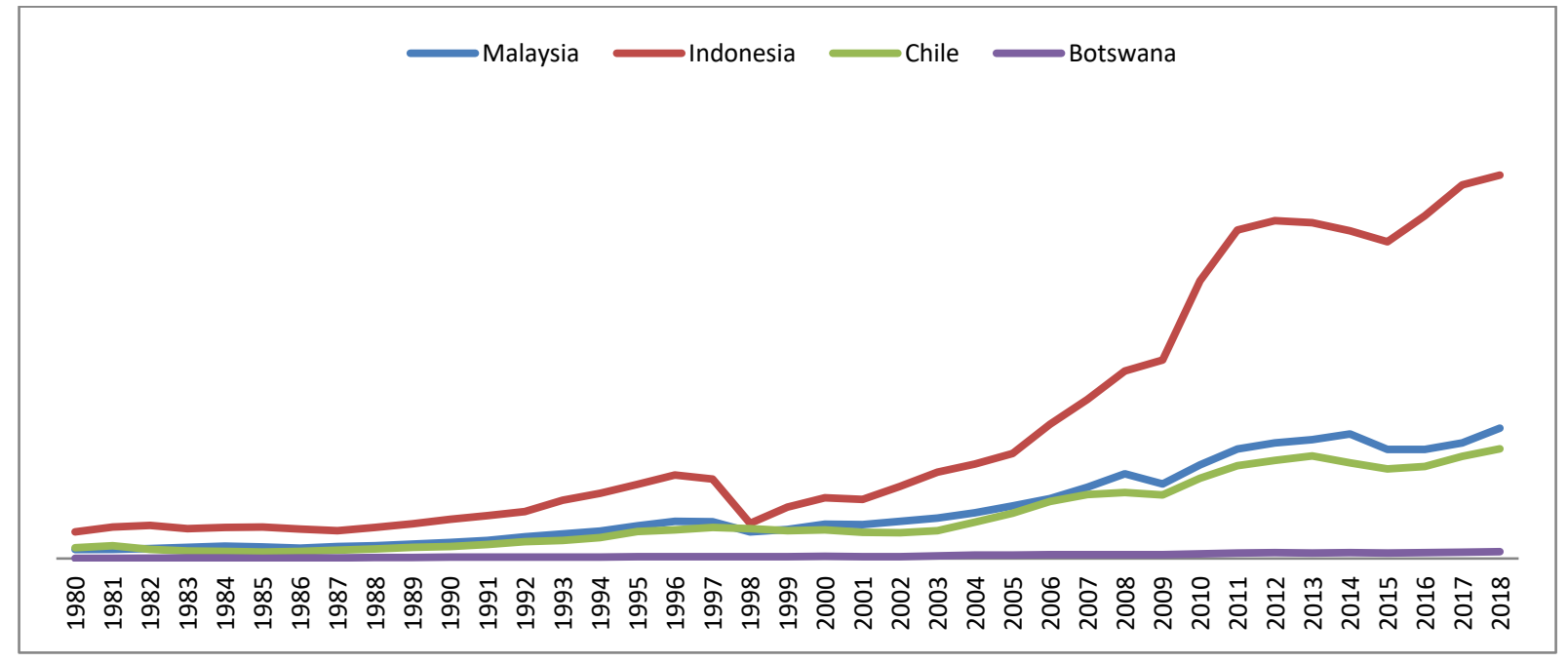

Source: The World Bank Data (2019).

Figure 5. GDP Growth for Cursed Resource-Rich Developing Countries (1980-2018) (US \$)

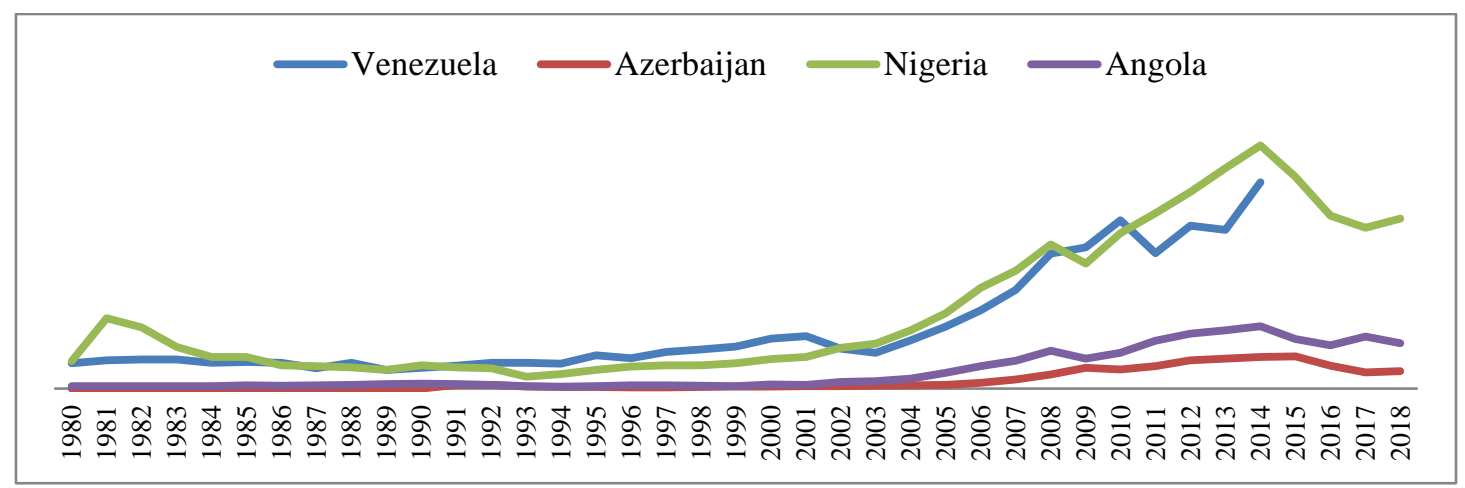

Source: The World Bank Data (2019), GDP (Current US\$). 
Figure 5 represents GDP growth of "cursed" selected resource-rich developing countries, Venezuela, Azerbaijan, Nigeria, and Angola. Contrary to Figure 3 and Figure 4, these countries are highly dependent on natural resource revenues. Therefore, natural resource price volatility in the global markets directly affects the local economies. As the oil prices decreased in the 2014-2016 period, there are sharp declines observed in the GDPs of Nigeria, Angola, and Azerbaijan. There was no data for 2016-2018 for Venezuela in the World Bank database. However, recent developments in Venezuela shows the great financial crisis.

In Figure 6 and Figure 7, resource-rich developed countries and resource-rich developing countries are sketched comparatively. Similar findings can be seen from the graphics. According to Graphic-6, Norway, Canada, and Australia showed sustainable GDP per capita growth with remarkable performance.

Figure 6. GDP Per Capita in Developed Resource-Rich Countries (US\$)

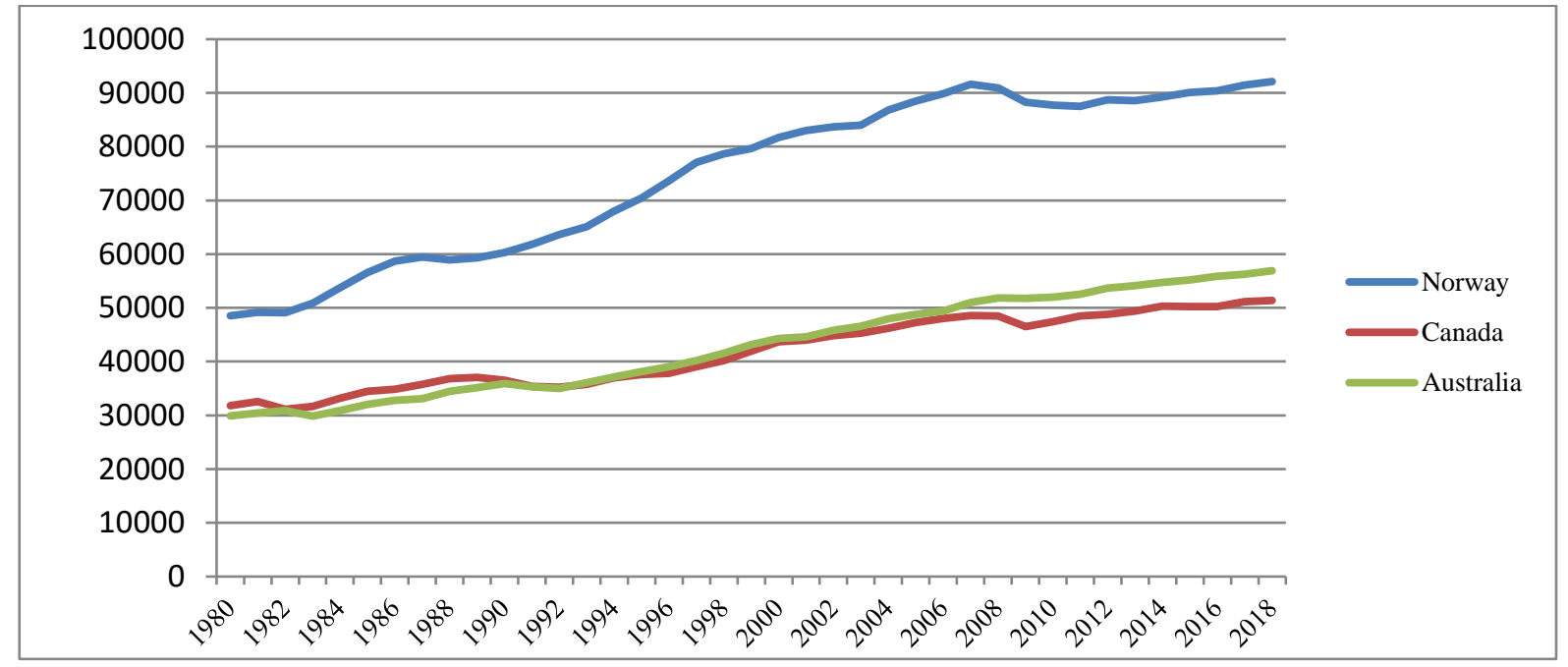

Source: The World Bank Data (2019), GDP Per Capita (Current US\$).

According to Figure 7, GDP per capita has not increased enough comparing with increasing natural resource revenues in those countries. There was no data for Venezuela for the 2016-2018 period. In Azerbaijan, Nigeria, and Angola, GDP per capita stayed almost the same between 2008-2018 despite having great revenues after the Global Crisis.

Figure 7. GDP Per Capita in Developing Resource-Rich Countries (US\$)

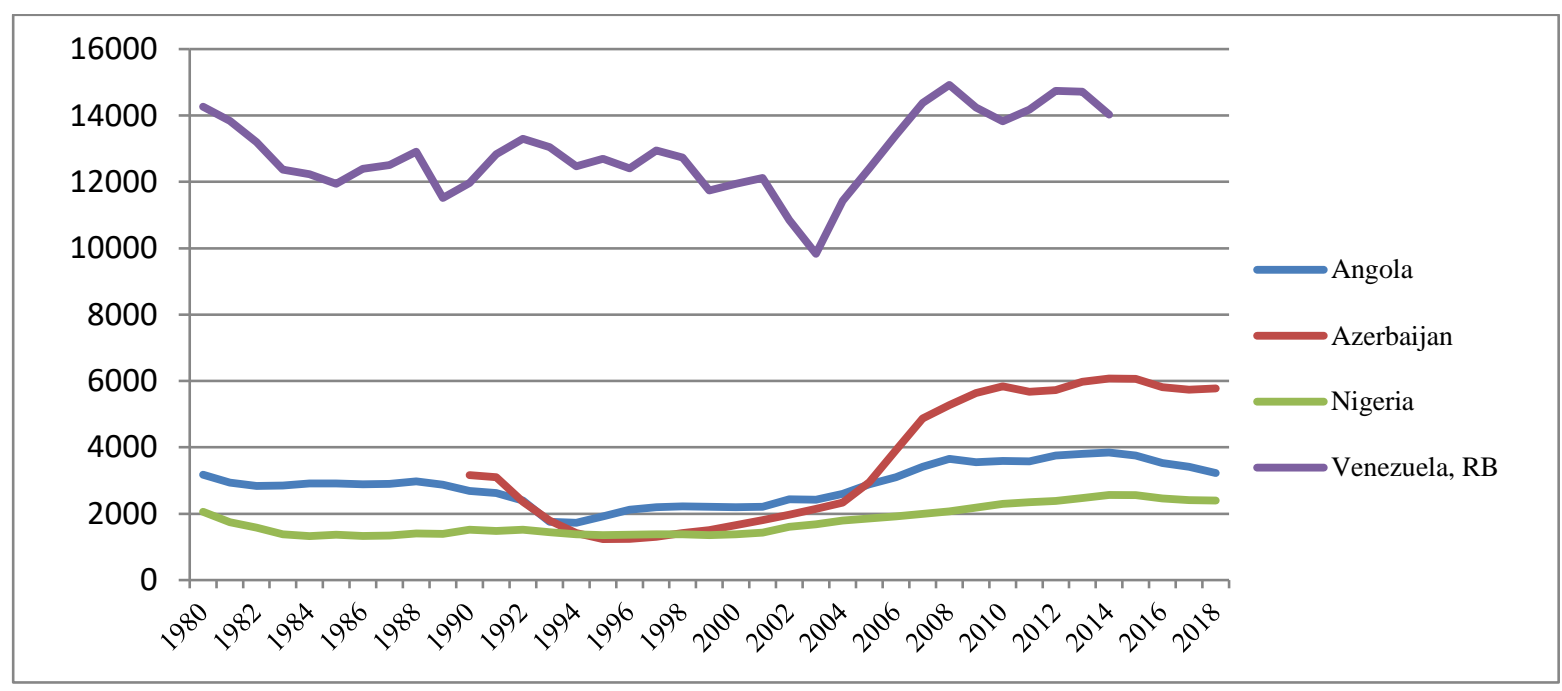

Source: The World Bank Data (2019), GDP Per Capita (Current US\$). 
Governments of natural resource-abundant countries tend to spend more to establish a generous welfare state. Nevertheless, if the economic structure is not well-functioning, this policy is not sustainable. Furthermore, resource-rich countries have a tendency to borrow more. If resources have a high price on international markets, borrowings become excessive. However, if the price of natural resource shrinks or if natural resource is run out, the economical conditions worsen immediately and end up with a financial crisis (Arezki \& van der Ploeg, 2007: 3). As illustrated in Figure 8, despite having increasing natural resource revenues, natural resource-rich developing countries' external debt stock levels did not decrease. Contrary, in all selected countries, external debt stock increased. We could not find any external debt stock data for Canada, Norway, and Australia in the World Bank database.

Figure 8. External Debt Stock of Developing Resource-Rich Countries (Current US\$)

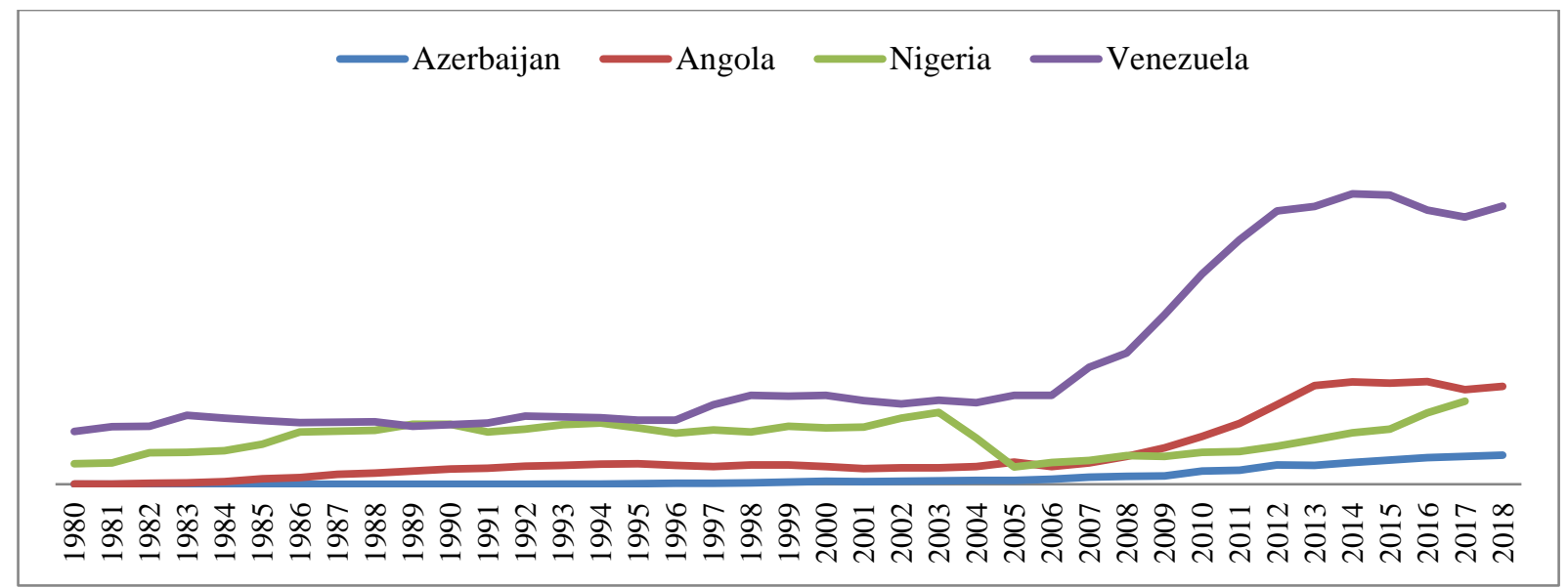

Source: The World Bank Data (2019), External Debt Stock (Current US\$).

\section{Conclusion}

In this paper, natural resource windfall and economic growth relationship was analyzed. It was concluded that in many "cursed" resource-rich developing countries, Dutch Disease, excessive rent-seeking, lack of democracy, and inadequate institutionalization are common problems. Imperfect democracy and political elitism provide a suitable ecosystem for corruption. It is a fact that having natural resources is a gift for the owner country. The "curse" starts if the gifted country cannot manage it wisely. The countries such as Norway, Canada, and Australia enjoyed having natural resource windfall.

To get the benefits of natural resource abundance, countries should take certain precautions into account. First of all, in the boom period of natural resource revenues, there is always a risk of overvaluation of the local currency. Since overvalued currency represses export sectors, manufacturing and service industries suffer from this process. If there is no precaution, this process ends with crowding-out of manufacturing and other areas. To manage the overvaluation of the domestic currency, monetary policy becomes very important. Besides, independent and the accountable central bank is also very critical in managing process. Diversification in the economy is another critical issue. In most of the developing natural resource-rich countries, governments ignore the other sectors since there is sufficient revenue coming from natural resource extraction and export. However, in the burst periods, when there are high fluctuations in the local economy, the performance of the other sectors is essential to avoid an economic crisis. In Norway and Canada, the percentage of natural resource export in total GDP is much lower than in Azerbaijan and Nigeria. Good fiscal policy is another critical factor in managing natural resource revenues. Government and political elites should have limited power on spending decisions on natural revenues. If there are more transparency and accountability as well as a well-functioning check and balance mechanism, then policymakers will be more careful about spending decisions. Well-designed legislation and tax law may be very beneficial in controlling the political authorities. As a conclusion, it can be said that in a suitable functioning mechanism, natural resource abundance provides excellent opportunities to the owner country. 


\section{References}

Ades, A., \& Di Tella, R. (1999). Rents, competition, and corruption. The American Economic Review, 89(4), $982-993$.

Amundsen, I. (2017). Nigeria: Defying the resource curse. In A. Williams \& P. Le Billon (Ed.), Corruption, natural resources, and development (pp.17-27). Cheltenham, UK: Edward Elgar Publishing.

Arezki, R., \& van der Ploeg, F. (2007). Can the natural resource curse be turned into a blessing? The role of trade policies and institutions. IMF Working Paper, WP/07/55.

Atkinson, G., \& Hamilton, K. (2003). Savings, growth and the resource curse hypothesis. World Development, 31(11), 1793-1807.

Busse, M. \& Gröning, S. (2013). The resource curse revisited: Governance and natural resources. Public Choice, 154(1/2), $1-20$.

Carmignani, F. (2013). Development outcomes, resource abundance, and transmission through inequality. Resource and Energy Economics, 35(3), 412-428.

Caselli, F. (2006). Power struggles and the natural resource curse. LSE Research Online, Working Paper. http://eprints.Ise.ac.uk/4926/

Caselli, F., \& Cunningham, T. (2009). Leader behavior and the natural resource curse. Oxford Economic Papers, 61, 628650.

Cust, J., Halonen, A. B., \& Harding, T. (2018). The resource curse: Only for the selected few. October 26, 2018. Retrieved July 27, 2019, from https://pdfs.semanticscholar.org/e140/4c531d545d4635ca0758277556bfe4940cd0.pdf

Di John, J. (2011). Is there really a resource curse? A critical survey of theory and evidence. Global Governance, 17, 167184.

Feltenstein, A. (1992). Oil price and rural migration: The Dutch disease goes south. Journal of International Money and Finance, 11, 273-291.

Gerelmaa, L., \& Kotani, K. (2016). Further investigation of natural resources and economic growth: Do natural resources depress economic growth? Resources Policy, 50, 312-321.

Goderis, B., \& Malone, S. W. (2011). Natural resource booms and inequality: Theory and evidence. Scand. J. of Economics, 113(2), 388-417.

Gylfason, T. (2011). Natural resource endowment: A mixed blessing? In R. Arezki, T. Gylfason \& A. Sy (Ed.), Beyond the Curse: Policies and harness the power of natural resources. Washington DC: IMF Publishing.

Holden, S. (2013). Avoiding the resource curse: The case Norway. Energy Policy, 63, 870-876.

Isham, J., Woolcock, M., Pritchett, L., \& Busby, G. (2002). The varieties of rentier experience: How natural resource export structures affect the political economy of economic growth. March 15, 2002. Retrieved July 29, 2019 from https://pdfs.semanticscholar.org/4152/9fcbaa4e1996aa460f4dc8025b518529fbfb.pdf

Karabegovic, A. (2009). Institutions, economic growth, and the "curse" of natural resources. F. MacMahon (Series Ed.), Studies in Mining Policy, Fraser Institute.

Karamelikli, H., Akalin, G., \& Arslan, U. (2017). Oil exports and non-oil exports, Dutch disease effects in the organization of Petroleum Exprting Countries (OPEC). Journal of Economic Studies, 44(4), 540-551.

Kumar, H., Toshniwal, A., \& Gupta, S. (2016). The resource curse play: A comparative study of Norway and Venezuela. IOSR Journal of Economics and Finance, 7(5), 13-20.

Larsen, E. R. (2006). Escaping the resource curse and Dutch Disease? When and why Norway caught up with the forged ahead of its neighbors. The American Journal of Economics and Sociology, 65(3), 605-640.

Lujala, P., \& Epremian, L. (2017). Transparency and natural resource revenue management: Empowering the public with information? In A. Williams \& P. Le Billon (Ed.), Corruption, natural resources and development (pp. 58-68). Cheltenham, UK: Edward Elgar Publishing.

Macrotrends (2019). Crude oil prices - 70-year historical chart. Retrieved July 29, 2019 from https://www.macrotrends.net/1369/crude-oil-price-history-chart

Matsen, E., \& Torvik, R. (2005). Optimal Dutch Disease. Journal of Development Economics, 78, 494-515.

Mehlum, H., Moene, K., \& Torvik, R. (2006). Institutions and the resource curse. The Economic Journal, 116, 1-20.

Moradbeigi, M., \& Law, S. H. (2016). Growth volatility and resource curse: Does financial development dampen oil shocks? Resources Policy, 48, 97-103. 
Mosley, P. (2017). Fiscal policy and the natural resource curse, how to escape from the poverty trap. New York: Routledge Publishing.

Partridge, M. D., Betz, M. R., \& Lobao, L. (2013). Natural resource curse and poverty in Appalachian America. American Journal of Agricultural Economics, 95(2), 449-456.

Pegg, S. (2016). Is there a Dutch disease in Botswana? Resources Policy, 35, 14-19.

Reisinezhad, A. (2018). Economic growth and income inequality in resource countries: Theory and evidence. Paris School of Economics, Working Paper, No. 2018-05.

Ross, M. L. (2012). The oil curse, how petroleum wealth shapes the development of nations. New Jersey: Princeton University Press.

Ruehle, A. A., \& Kulkarni, K. G. (2011). Dutch disease and the Chilean copper boom-empirical analysis. International Journal of Education Economics and Development, 2(1), 61-80.

Sachs, J. D., \& Warner, A. M. (1995). Natural resource abundance and economic growth. NBER Working Paper, 5398.

Sachs, J. D., \& Warner, A. M. (2001). Natural resource and economic development, the curse of natural resources. European Resources and Economic Development, 45, 827-838.

Sala-i Martin, X., \& Subramania, A. (2003). Addressing the natural resource curse: An illustration from Nigeria. IMF Working Paper, WP/03/139.

Shao, S., \& Yang, L. (2014). Natural resource dependence, human capital accumulation, and economic growth: A combined explanation for the resource curse and resource blessing. Energy Policy, 74, 632-642.

Steven, P. (2003). Resource impact: Curse or blessing? A literature survey. Journal of Energy Literature, 9(1), 1-42.

Taguchi, H., \& Soukvisan, K. (2017). Analysis of the "Dutch Disease" effect: The case of resource-rich ASEAN economies. MPRA, Paper No. 81010.

Tenorio, A. C. (2013). Three papers o the political consequences of oil prices. Ph.D. Thesis, All Theses and Dissertations (ETDs), 1128, Washington University Open Scholarship.

The World Bank Data (2019). GNI Per Capita. Retrieved August 01, 2019 from https://data.worldbank.org/?locations=TM-RU-AZ-KZ

The World Bank Data (2019). GDP (Current US\$). Retrieved August 01, 2019 from https://data.worldbank.org/indicator/NY.GDP.MKTP.CD?locations=TM

Transparency International (2018). Corruption Perception Index 2018. Retrieved July 29, 2019 from https://www.transparency.org/cpi2018\#results

UN Environment (2019). Global resources outlook 2019, natural resources for the future we want. UN Environmental Program, DTI/2226/NA. Retrieved August 01, 2019 from https://wedocs.unep.org/handle/20.500.11822/27519

Veisi, M. (2017). Essays on the link between natural resources, corruption, taxation, and economic growth. Ph.D. Thesis, The University of Manchester, School of Social Sciences, Faculty of Humanities, Department of Economics.

Wick, K., \& Bulte, H. (2006). Contesting resources-rent seeking, conflict and the natural resource curse. Public Choice, $128(3 / 4), 457-476$.

Wick, K., \& Bulte, H. (2009). The curse of natural resources. Annual Review of Resource Economics, 1, 139-155.

Wieprzowski, P. (2013). Copper in Chile- when the resource "curse" becomes a blessing. International Journal of Management and Economics, 40, November-December, 141-154.

World Energy Council (2016). World energy resources. 
This Page Intentionally Left Blank 